\title{
TINJAUAN KRITIS TERHADAP PERATURAN GUBERNUR NOMOR 5 TAHUN 2018 TENTANG PELAKSANAAN HUKUM ACARA JINAYAH
}

\author{
Chadijah Rizki Lestari ${ }^{1}$, Basri Efendi ${ }^{2}$ \\ ${ }^{1,2}$, Dosen Fakultas Hukum Universitas Syiah Kuala \\ Jl. Putroe Phang No.1, Darussalam, Banda Aceh, 23111 \\ ${ }^{1}$ chadijah.rizki@gmail.com, ${ }^{2}$ basrieffendi83@gmail.com
}

\begin{abstract}
The Aceh Government has enacted Islamic Sharia provisions by establishing Aceh Qanun Number 7 of 2013 concerning the Jinayat Procedure Law. Where in Article 262 of Qanun Aceh Number 7 of 2013 contains rules regarding the implementation of caning sentences carried out in the open. However, based on the provisions of Article 30 Paragraph (3) the Governor of Aceh Regulation Number 5 Year 2018 concerning the Implementation of Jinayah Procedure Law has limited the implementation of whips in open places by whipping in prisons / remand centers / detention centers. Research uses normative juridical methods that are eksplanataris. The results of the study indicate that the main reason for the issuance of the governor's regulation was the reason for the Governor to increase investment because the implementation of caning in Aceh received opposition from outside parties. So it is unfortunate that the issuance of the Governor Regulation contradicts the system for establishing legislation in Indonesia. Therefore juridically the governor's regulation has no legal force.

Keywords: Critical Review, Governor Regulation Number 5 Year 2018, Jinayah Procedural Law
\end{abstract}

\begin{abstract}
Abstrak, Pemerintah Aceh telah memberlakukan ketentuan syariat Islam dengan menetapkan Qanun Aceh Nomor 7 Tahun 2013 tentang Hukum Acara Jinayat. Dimana dalam Pasal 262 Qanun Aceh Nomor 7 Tahun 2013 memuat aturan mengenai pelaksanaan hukuman cambuk yang dilakukan di tempat terbuka. Namun, berdasarkan ketentuan Pasal 30 Ayat (3) Peraturan Gubernur Aceh Nomor 5 Tahun 2018 tentang Pelaksanaan Hukum Acara Jinayah telah membatasi pelaksanaan cambuk di tempat terbuka dengan dilakukannya cambuk di lembaga pemasyarakatan/rutan/cabang rutan. Penelitian menggunaan metode yuridis normative yang bersifat eksplanataris. Hasil penelitian menunjukkan bahwa alasan utama dikeluarkannya peraturan gubernur adalah alasan Gubernur untuk meningkatkan investasi karena pada pelaksanaan hukuman cambuk di Aceh mendapat pertentangan dari pihak luar. Sehingga sangat disayangkan keluarnya Pergub tersebut bertentangan dengan sistem pembentukan peraturan perundang-undangan di Indonesia. Oleh karena itu secara yuridis peraturan gubernur tersebut tidak memiliki kekuatan hukum.

Kata Kunci : Tinjauan Kritis, Peraturan Gubernur Nomor 5 Tahun 2018, Hukum Acara Jinayah
\end{abstract}

\section{Pendahuluan}

Undang-Undang Nomor 44 Tahun 1999 Tentang Penyelenggaraan Keistimewaan Provinsi Daerah Istimewa Aceh (UU Nomor 44 Tahun 1999) telah memberikan keistimewaan kepada rakyat Aceh untuk melaksanakan dan menyelenggarakan beberapa 
bidang kehidupan. Diantara keistimewaan yang diberikan adalah sebagaimana yang disebut dalam Pasal 3 Ayat (2) UU Nomor 44 Tahun 1999 yaitu penyelenggaraan kehidupan di beberapa bidang seperti penyelenggaraan kehidupan beragama; penyelenggaraan kehidupan adat; penyelenggaraan pendidikan; dan peran ulama dalam penetapan kebijakan daerah. Penerapan otonomi daerah pasca reformasi menitik beratkan pada kemandirian daerah provinsi dalam membangun rumah tangga sendiri. Menurut konsep otonomi terbagi dalam tiga yaitu otonomi biasa, otonomi istimewa dan otonomi khusus, yang ditekankan dalam Pasal 18, Pasal 18A dan Pasal 18B UUD $1945 .{ }^{1}$

Adapun tujuan Pemerintah Aceh menyelenggarakan syariat Islam secara kaffah dilakukan dengan mewujudkan sejumlah qanun bidang syariat Islam. Dimana sebelumnya telah ditetapkan dengan diberlakukannya Qanun Nomor 12 Tahun 2003 tentang Minuman Khamar, Qanun Nomor 13 Tahun 2003 tentang Maisir, dan Qanun Nomor 14 Tahun 2003 tentang Khalwat. ${ }^{2}$ Konsekuensi penyelenggaraan kehidupan beragama sebagaimana dimaksud diatas adalah penegakan syariat Islam bagi setiap pemeluknya, yaitu melakukan segala perbuatan yang diperintahkan oleh Allah SWT dan Rasul-NYA dan menjauhi setiap larangannya. setiap perbuatan tersebut akan menjadi landasan bagi Pemerintah Aceh dalam membuat dan mengeluarkan peraturan daerah.

Salah satu Qanun sebagai implikasi aturan mengenai perbuatan yang dilarang menurut syariat islam adalah Qanun Aceh Nomor 6 Tahun 2014 tentang Hukum Jinayat (Qanun Hukum Jinayat). Berdasarkan ketentuan Pasal 1 Angka 15; Angka 16; Angka 17; Angka 18; dan Angka 19 Qanun Hukum Jinayat diketahui bahwa hukum jinayat merupakan hukum yang mengatur tentang perbuatan yang dilarang oleh syariat islam (jarimah) yang dalam Qanun tersebut diancam dengan 'uqubat hudud dan /atau ta'zir. ${ }^{3}$ Perbuatan-perbuatan jarimah tersebut menurut Pasal 3 Ayat (2) Qanun Jinayat antara lain: (a) khamar; (b) maisir; (c) khalwat; (d) ikhtilah; (e) zina; (f) pelecehan seksual; (g) pemerkosaan; (h) Qadzaf; (i) Liwath; dan (j) musahaqah.

Salah satu'uqubat yang dapat dijatuhkan hakim kepada pelaku yang terbukti secara sah dan meyakinkan telah sengaja melakukan perbuatan jarimah adalahhukumancambuk.Jumlah cambukan yang diterima pelaku sangat tergantung pada jenis dan bentuk perbuatan jarimah yang dilakukan. Misalkan saja seorang pelaku akan dihukum 40 (empat puluh) kali cambukan apabila ia terbukti telah dengan sengaja minum khamar untuk pertama kali berdasarkan putusan pengadilan yang tetap. Lain halnya dengan dengan perbuatan zina, jumlah cambukan yang akan diterima mencapai 100 (seratus) kali cambukan. ${ }^{4}$

1 Zaki Ulya, Refleksi Memorandum of Understanding (MoU) Helsinki Dalam Kaitan Makna Otonomi Khusus Di Aceh, Jurnal Konstitusi, Volume 11, Nomor 2, Juni 2014, hlm. 372

${ }^{2}$ Zaki Ulya, Dinamika Penerapan Hukum Jinayat Sebagai Wujud Rekonstruksi Syariat Islam di Aceh, Jurnal Rechtsvinding, Volume 5 Nomor 1 Tahun 2016, hlm. 136

3 'uqubat adalah hukuman yang dapat dijatuhkan oleh hakim terhadap pelaku jarimah; hudud adalah jenis 'uqubat yang bentuk dan besarannya telah ditentukan dalam qanun secara tegas; ta'zir adalah jenis 'uqubat yang telah ditentukan dalam qanun yang bentuknya bersifat pilihan dan besarannya dalam batas tertinggi dan/atau terendah.

${ }^{4}$ Lihat Pasal 15 Ayat (1) dan 33 Ayat (1) Qanun Hukum Jinayat. Jumlah cambukan yang diterima oleh terhukum tersebut adalah berdasarkan ketentuan yang ditetapkan dalam Al-qur'an. 
Pelaksanaan hukuman jarimah terhadap terhukum nantinya akan dilaksanakan di tempat terbuka dan dapat dilihat oleh orang yang hadir. Hal tersebut sebagaimana yang dimanatkan oleh Pasal 262 Qanun Aceh Nomor 7 Tahun 2013 Tentang Hukum Acara Jinayat (selanjutnya disingkat dengan Qanun Hukum Acara Jinayat). Berdasarkan hal tersebut, masyarakat kemudian memilih tempat-tempat terbuka seperti halaman masjid sebagai lokasi pelaksanaan hukuman cambuk.

Pemilihan lokasi hukuman cambuk di tempat terbuka ternyata menuai polemik. Ada beberapa kalangan, khususnya pihak asing menganggap bahwa pelaksanaan hukuman cambuk di tempat terbuka telah melanggar hak asasi manusia. Hal tersebut membuat Gubernur Aceh mengeluarkan Peraturan Gubernur Nomor 5 Tahun 2018 Tentang Pelaksanaan Hukum Acara Jinayah (selanjutnya disingkat Pergub Acara Jinayah).Dalam Pasal 30 ayat (3) Pergub Acara Jinayah diketahui bahwa yang dimaksud tempat terbuka untuk pelaksanaan hukuman cambuk adalah lembaga pemasyarakatan/Rutan/Cabang Rutan.

Pergub Acara Jinayah tersebut membuat protes keras dari DPRA. Ketua DPRA, Muharuddin menyatakan bahwa Pergub tersebut telah melanggar aturan dan tidak prosedural. ${ }^{5}$ Berdasarkan hal tersebut diatas penulis tertarik mengkaji tentang tinjauan yuridis kedudukan Pergub Acara Jinayah terhadap Qanun Hukum Acara Jinayah.

\section{Metode Penelitian}

Kajian ini menggunakan yuridis normative yang bersifat eksplanataris. Sehingga data yang digunakan yaitu data sekunder yang mencakup bahan hukum primer, bahan hukum sekunder dan bahan hukum tersier. Setelah bahan dikumpulkan maka akan diklasifikasikan dan diolah secara kualitatif. ${ }^{6}$

\section{Pembahasan}

\section{Teori kewenangan}

Istilah wewenang mempunyai posisi yang sejajar dengan authority dalam bahasa Inggris. Authority dalam Black's Law Dictionary bermakna kekuasaan hukum, hak untuk memerintah atau bertindak; hak atau kekuasaan pejabat publik untuk mematuhi aturan hukum dalam lingkup melaksanakan kewajiban publik. ${ }^{7}$ Sedangkan secara literatur, para ahli telah mencoba mendefinisikan arti kata wewenang.Sebut saja Philipus M Hadjon, ia mendekripsikan wewenang sebagai kekuasaan hukum. $^{8}$ Lalu H.D. Stout yang menyebutkan bahwa wewenang sebagai keseluruhan aturan yang berkenaan dengan

\footnotetext{
${ }^{5} \mathrm{http}: / /$ aceh.tribunnews.com/2018/04/21/dpra-sepakat-gugat-pergub-apba-dan-pergub-cambuk, diakses tanggal 18 Juli 2018.

${ }^{6}$ H. Zainuddin Ali, Metode Penelitian Hukum, (Jakarta: Sinar Grafika, 2009), hlm. 24

7 https://anzdoc.com/bab-ii-landasan-teori7a2ecde0d71d8d383bb316db3b62c23e19397.html, diakses tanggal 27 juli 2018.

${ }^{8}$ Syofyan Hadi, "Teori

Kewenangan”,https://www.academia.edu/5708875/TEORI_KEWENANGAN?auto=download, diakses tanggal 23 juli 2018.
} 
perolehan dan penggunaan wewenang-wewenang pemerintahan oleh subjek hukum publik di dalam hubungan hukum publik. ${ }^{9}$

Berdasarkan pengertian tersebut diatas dapat diketahui bahwa wewenang memiliki kedudukan penting dalam kajian hukum tata negara dan hukum administrasi negara. Setiap perbuatan dan keputusan yang dikeluarkan pemerintah harus selalu berlandaskan kepada wewenang yang dimiliki. Hal ini sejalan dengan asas legalitas yang merupakan prinsip utama dalam negara hukum yang sering dirumuskan dengan ungkapan "het beginsel van wetmatigheid van bestuur" yakni prinsip keabsahan pemerintahan. ${ }^{10}$

Ditinjau dari sumber perolehannya, terdapat 3 kategori kewenangan, yaitu:

1. Kewenangan atributif

Adalah kewenangan yang diberikan langsung oleh peraturan perundang-undangan. Terhadap kewenangan atributif tanggung jawab dan tanggung gugat berada pada pejabat atau badan sebagaimana tertera pada peraturan dasarnya.

2. Kewenangan delegatif

Adalah kewenangan yang bersumber dari pelimpahan suatu organ pemerintahan kepada organ lain dengan dasar peraturan perundang-undangan. Terhadap kewenangan delegatif tanggung jawab dan tanggung gugat beralih kepada yang diberi wewenang tersebut dan beralih kepada delegataris

3. Kewenangan mandat

Merupakan kewenangan yang bersumber dari proses atau prosedur pelimpahan dari pejabat atau badan yang lebih tinggi kepada pejabat yang lebih rendah. Kewenangan mandat terdapat dalam hubungan rutin atasan dan bawahan, kecuali bila dilarang secara tegas.

\section{Konsep Negara Hukum}

Konsep mengenai negara hukum telah dikembangkan sejak zaman Plato dan Aristoteles. Plato (429-374 SM) mencoba menjabarkan bentuk negara ideal melalui karya-karyanya. Sehingga pada buku yang dihasilkan pada masa tuanya yaitu nomoi, ia secara tegas menyatakan bahwa adanya peraturan-peraturan hukum dalam sebuah negara menjadi sebuah keharusan. ${ }^{11}$ Kemudian, dilanjutkan oleh muridnya Aristoteles (384-322 SM)yang mensyaratkan adanya konstitusi dan kedaulatan hukum dalam suatu negara. ${ }^{12}$

Pada periode selanjutnya, pemikiran tentang negara hukum semakin berkembang. Para filsuf mencoba membahas masalah tersebut untuk menemukan bentuk negara ideal

\footnotetext{
${ }^{9}$ Abdul Rauf Alaudin Said, "Pembagian Kewenangan Pemerintah Pusat-Pemerintah Daerah Dalam Otonomi Seluas-luasnya menurut UUD 1945", https://media.neliti.com/media/publications/37009-ID-pembagian-kewenangan-pemerintah-pusatpemerintah-daerah-dalam-otonomi-seluas-lua.pdf, diakses tanggal 23 juli 2018.

${ }^{10}$ Ridwan HR, Hukum Administrasi Negara, (Jakarta: Rajawali Pers, 2013), hlm.91.

${ }^{11}$ Azhari, Negara Hukum Indonesia, Analisis Yuridis Normatif Tentang Unsur-Unsurnya, (Jakarta: UI-Press, 1995), hlm.12.

12 Sayuti, "Konsep Rechtsstaat dalam Negara Hukum Indonesia", hlm.82, melalui https://media.neliti.com/media/publications/220458-konsep-rechtsstaat-dalam-negara-hukumin.pdf, diakses tanggal 24 juli 2018.
} 
yang sesuai dengan eranya. Peristilahan tentang Negara hukum juga disesuaikan sesuai dengan zamannya. Sebagai contoh, di era modern saat inikonsep negara hukum dipengaruhi oleh 2 (dua) system hukum dunia, yaitu eropa continental dengan "rechtsstaat" nya, dan pada anglo saxon dengan "rule of law". Kedua istilah tersebut memiliki system dan pelaksanaan yang sedikit berbeda namun memiliki tujuan yang sama yaitu menyelenggarakana pemerintahan berdasarkan hukum.

Indonesia juga merupakan salah satu negara hukum. Hal ini sesuai dengan Pasal 1 Ayat 3 UUD 1945 Amandemen yang menyatakan bahwa "Negara Indonesia adalah negara hukum".Namun, konsep negara hukum yang dianut Indonesia berbeda dengan konsep negara hukum pada eropa continental dan anglo saxon, karena negara hukum Indonesia berlandaskan kepada Pancasila. ${ }^{13}$

\section{Kedudukan Qanun dalam System Hukum Indonesia}

Pancasila sebagai falsafah pandangan hidup bangsa Indonesia memiliki kedudukan penting dalam struktur tata hukum nasional. Menggunakan teori Hans Kelsen yaitu teori piramida hukum (stufentheorie) yang kemudian dikembangkan oleh muridnya Hans Nawiasky, dapat ditarik kesimpulan bahwa Pancasila merupakan norma fundamental negara.

Norma fundamental negara merupakan norma yang menjadi dasar pembentukan konstitusi atau undang-undang dasar suatu negara. Suatu konstitusi mensyaratkan norma fundamental negara sebagai landasan haluan arah kebijaksanaan negara. Kemudian dalam teori Nawiasky, ada beberapa urutan norma setelah norma fundamental, yaitu aturan dasar negara; undang-undang formal; dan peraturan pelaksana dan peraturan otonom. ${ }^{14}$ Dikaitkan dengan hierarki peraturan perundang-undangan di Indonesia, Pasal 7 UndangUndang Nomor 12 Tahun 2011 Tentang Pembentukan Peraturan perundang-undangan menentukan tata urut peraturan perundang-undangan di Indonesia yaitu UUD NKRI 1945; Ketetapan MPR; UU/Perpu; Peraturan Pemerintah; Peraturan Presiden; Peraturan Daerah Provinsi; Peraturan Daerah Kota/Kabupaten.

Aceh merupakan salah satu provinsi di Indonesia yang memiliki kekhususan tersendiri. Dengan mempertimbangkan karakteristik perjuangan rakyat Aceh dalam mencapai kemerdekaan serta beragamnya dinamika kehidupan tata negara setelah Indonesia merdeka, Aceh memperoleh keistimewaan dalam penyelenggaraan pemerintahan. Pasal 16 Ayat (2) Undang-Undang Nomor 11 Tahun 2006 Tentang Pemerintah Aceh menyebutkan kekhususan Aceh meliputi kewenangan penyelenggaraan kehidupan beragama dalam bentuk pelaksanaan syari'at Islam bagi pemeluknya di Aceh dengan tetap menjaga kerukunan hidup antar umat beragama; penyelenggaraan kehidupan adat yang bersendikan agama Islam; peyelenggaraan pendidikan yang berkualitas serta menambah materi muatan local sesuai syari'at Islam; peran ulama dalam penetapan kebijakan Aceh.

${ }^{13}$ Ibid, hlm.97.

$14 \mathrm{https} / /$ www.scribd.com/document/326281733/Pengaruh-Teori-Piramida-Hukum-Hans-KelsenDalam-Pembentukan-Undang-undang-Di-Indonesia, diakses tanggal 24 juli 2018. 
Qanun Hukum Jinayat hadir sebagai aturan tertulis dalam pelaksanaan syaria'at islam di Aceh. Tidak heran jika dalam penjelasannya disebutkan 4 (empat) prinsip utama yang menjadi pegangan dalam pembentukan qanun tersebut, yaitu bersumber kepada Alqur'an dan sunnah Rasulullah; penafsiran atau pemahaman atas Al-qur'an dan Hadist tersebut akan dihubungkan dengan keadaan dan kebutuhan local (adat) masyarakat Aceh pada khususnya serta dengan tata aturan yang berlaku dalam kerangka NKRI; penafsiran dan pemahaman tersebut akan diupayakan untuk selalu berorientasi kepada masa depan untuk memenuhi kebutuhan masyarakat Indonesia; serta tetap memakai ketentuanketentuan lama (mahzab) yang baik.

Implikasi terhadap prinsip utama tersebut diatas dapat dilihat dalam penerapan azas sebagaimana yang disebutkan Pasal 2 Qanun Hukum Jinayah, yaitu keislaman; legalitas; keadilan; keseimbangan; kemaslahatan; perlindungan hak asasi manusia; dan pembelajaran kepada masyarakat.

Ruang lingkup pengaturan pada Qanun Hukum Jinayah terdiri pada pelaku jarimah; jarimah; dan 'uqubat. ${ }^{15}$ hal tersebut sebagaimana yang ditentukan Pasal 3 Ayat (1) Qanun Hukum Jinayah. Pada Ayat (2) selanjutnya disebutkan jenis jarimah yang dimaksudkan yaitu khamar; maisir; khalwat;ikhtilah; zina; pelecehan seksual; pemerkosaan; qadzaf; liwath; dan musahaqah.Penentuantersebut dilakukan dengan mengikuti kaidah fiqh yang ada. Nantinya, pelaku jarimah yang terbukti bersalah secara hukum akan dikenakan 'uqubat hudud dan 'uqubat ta'zir, diantaranya adalah cambuk.

Penjatuhan hukuman cambuk sebenarnya sudah dilaksanakan sejak tahun 2005 silam. Lokasi pelaksanaannya sendiri dilakukan di tempat terbuka sebagaimana yang diamanahkan Pasal 262 ayat (1) Qanun Hukum Acara Jinayah. Namun, baik Qanun Hukum Jinayah dan Qanun Hukum Acara Jinayah tidak mendefinisikan secara limitative pengertian tempat terbuka tersebut.Dalam prakteknya sepanjang tempat tersebut sudah dianggap terbuka menurut pemahaman umum dan masyarakat maka sudah memenuhi persyaratan sebagaimana yang dimaksud Pasal tersebut.

Namun, kehadiran Pergub Hukum Acara Jinayah yang mengatur secara limitatif pengertian tempat terbuka menjadi pembahasan menarik dalam tulisan ini. Pertama, Sejatinya, gubernur dapat membentuk peraturan perundang-undangan berdasarkan delegasi dari peraturan daerah provinsi atau peraturan perundang-undangan yang lebih tinggi. ${ }^{16}$ Namun, baik Qanun Hukum Jinayah maupun Qanun Hukum Acara Jinayah tidak menugasi gubernur untuk mengatur lebih lanjut mengenai tata cara pelaksanaan cambuk. Tanggung Sejatinya mengacu Pasal 252 Qanun Hukum Acara Jinayah jaksalah yang bertanggung jawab menentukan tempat dan waktu pelaksanaan 'uqubat cambuk setelah berkoordinasi dengan dengan Ketua Mahkamah Syari'ah, Kepala Dinas Kesehatan, dan Instansi yang membawahi Wilayatul Hisbah kabupaten/kota setempat.

Kedua Apabila melihat dari segi penggunaan bahasa, meskipun Qanun tidak mengatur secara limitative pengertian tempat terbuka namun kaidah pada Pasal 262 ayat

\footnotetext{
15 Jarimah adalah perbuatan yang dilarang oleh Syari'at Islam. 'uqubat adalah hukuman yang dapat dijatuhkan oleh hakim terhadap pelaku jarimah.

${ }^{16}$ Maria Farida Indrati S, Ilmu Perundang-Undangan, Buku 1, (Jakarta,: Kanisius, 2013), hlm.107.
} 
(1) Qanun Hukum Acara Jinayah "Uqubat cambuk dilaksanakan di suatu tempat terbuka dan dapat dilihat oleh orang yang hadir" sudah sangat jernih dan terang. Meskipun Qanun tidak mendefinisikan tempat terbuka secara limitative, Maria Farida Indrati berpendapat bahwa penggunaan bahasa Indonesia dalam peraturan perundang-undangan adalah bahasa Indonesia yang umum dan baku. ${ }^{17}$ Sehingga pemaknaan kata "tempat terbuka" dapat mengacu pada Kamus besar Bahasa Indonesia (KBBI).

Menurut KBBI, tempat terbuka terdiri atas 2 (dua) kata, yaitu tempat dan terbuka. Pada frasa tempat, KBBI mendefinisikannyasebagai ruang (bidang, rumah, dan sebagainya) yang tersedia untuk melakukan sesuatu; bagian yang tertentu dari suatu ruang (bidang, daerah dan sebagainya). Sedangkan terbuka adalah tidak tertutup; tersingkap. ${ }^{18}$

Selain itu, pemaknaan kaidah bahasa dalam peraturan perundang-undangan dapat menggunakan penafsiran modern saat ini, yaitu"pendekatan atau prinsip tunggal". Penafsiran dengan "pendekatan atau prinsip tunggal"adalah kata-kata dalam peraturan hendaknya ditafsir dalam arti dan makna menurut tata bahasa yang biasa namun perlu dihubungkan dengan kehendak dan tujuan peraturan tersebut serta maksud para pembentuknya. $^{19}$

Dalam Islam, salah satu tujuan pemidanaan adalah sebagai pembelajaran kepada masyarakat. Tujuan tersebut kemudian diadopsi sebagai azas pada Qanun Hukum Acara Jinayah. Sehingga pada prakteknyauntuk memenuhi kriteria diatas, penyelenggara negara memilih halaman masjid sebagai lokasi pelaksanaan hukuman. Selain untuk memberikan efek jera kepada pelaku, juga sebagai peringatan kepada masyarakat agar tidak melakukan perbuatan serupa.

Tujuan tersebut tentu tidak akan tercapai apabila dilaksanakan berdasarkan Pasal 30 Ayat (3) Pergub Hukum Acara Jinayah yaitu di lembaga pemasyarakatan/Rutan/Cabang Rutan LP/Lapas/cabang Lapas. Karena tempat tersebut notabanenya adalah tempat tertutup. Biasanya masyarakat akan enggan hadir hanya untuk melihat prosesi cambuk. Akibatnya tujuan dari pemidanaan tersebut tidak akan tercapai.Pada tahapan lebih jauh, dikhawatirkan cambuk menjadi hukuman biasa yang tidak berperaruh bagi berkurangnya perbuatan jarimah.

Ketiga, prosedur pengeluaran Pergub Hukum Acara Jinayah bertentangan dengan Qanun Nomor 13 Tahun 2017 Tentang Tata Cara Pemberian Pertimbangan Majelis Permusyawaratan Ulama. Pada Pasal 11 ayat (1) dinyatakan bahwa "Setiap kebijakan Pemerintahan Aceh yang berkenaan dengan Syariat Islam harus mendapatkan pertimbangan MPU Aceh". Dimana bentuk pertimbangan adalah tertulis sebagaimana yang diamanatkan Pada Pasal 1 Angka 16 Qanun yang sama. Namun, pertimbangan ini tidak pernah dimintakan sebagaimana yang diungkapkan oleh Wakil Ketua MPU, Tgk.Faisal Ali dalam serambi Indonesia online. ${ }^{20}$

Keempat, jika yang dipermasalahkan adalah rekaman foto atau video yang mungkin diambil serta adanya anak-yang yang hadir menyaksikan prosesi hukuman

\footnotetext{
${ }^{17}$ Ibid., hlm. 199.

${ }^{18}$ https://kbbi.web.id/tempat.

${ }^{19}$ Opcit., Maria Farida Indrati, hlm.204-205.

${ }^{20}$ Serambi Online, 15/4/2018.
} 
cambuk, maka masih ada alternatif solusi yang dapat ditempuh misalnya dengan meningkatkan prosedur penjagaan dan persyaratan yang ketat. Kesemua tahapan tersebut dapat diambil tanpa menghilangkan tujuan pemidanaan Islam sebagai syari'at agama yang dipegang teguh masyarakat Aceh.

\section{Penutup}

Pasal 30 Ayat (3) Pergub Hukum acara Jinayah hadir bukan untuk melaksanakan tugas yang diperintahkan oleh Qanun Hukum Jinayah dan Qanun Hukum Acara Jinayah, namun hadir karena alasan investasi sebagaimana yang diungkapkan oleh Gubernur Aceh dalam berbagai kesempatan.Padahal konstitusi sudah menentukan bahwa Provinsi Aceh memiliki kekhususan tersendiri, dimana Pemerintahan Aceh berwenang untuk melaksanakan Syariat Islam dalam kehidupan sehari-hari. Maka secara yuridis, ketentuan Pasal 30 Ayat (3) Pergub Hukum acara Jinayah tidak memiliki kekuatan hukum.

Mengingat Pasal 30 Ayat (3) Pergub Hukum acara Jinayah tersebut bertentangan dengan aturan hukum yang lebih tinggi, maka salah satu cara yang dapat dilakukan adalah melakukan uji materiil ke Mahkamah Agung.

\section{Daftar Pustaka}

\section{Buku}

Azhari, Negara Hukum Indonesia, Analisis Yuridis Normatif Tentang Unsur-Unsurnya, UI-Press, Jakarta, 1995

Maria Farida Indrati S, Ilmu Perundang-Undangan, Buku 1, Kanisius, Jakarta, 2013

Ridwan HR, Hukum Administrasi Negara, Rajawali Pers, Jakarta, 2013

Zainuddin Ali H., Metode Penelitian Hukum, Sinar Grafika, Jakarta, 2009

Zaki Ulya, Dinamika Penerapan Hukum Jinayat Sebagai Wujud Rekonstruksi Syariat Islam di Aceh, Jurnal Rechtsvinding, Volume 5 Nomor 1 Tahun 2016

Zaki Ulya, Refleksi Memorandum of Understanding (MoU) Helsinki Dalam Kaitan Makna Otonomi Khusus Di Aceh, Jurnal Konstitusi, Volume 11, Nomor 2, Juni 2014

\section{Peraturan Perundang-Undangan}

Undang-Undang Dasar Negara Republik Indonesia Tahun 1945

Undang-Undang Nomor 44 Tahun 1999 tentang Penyelenggaraan Keistimewaan Bagi

Provinsi Daerah Istimewa Aceh

Undang-Undang Nomor 11 Tahun 2006 tentang Pemerintahan Aceh

Qanun Aceh Nomor 7 Tahun 2013 tentang Hukum Acara Jinayat

Qanun Nomor 6 Tahun 2014 tentang Hukum Jinayat

Peraturan Gubernur Aceh Nomor 5 Tahun 2018 Tentang Pelaksanaan Hukum Acara Jinayah 
Volume 13, Nomor 2, Juli-Desember 2018

\section{Internet}

http://aceh.tribunnews.com/2018/04/21/dpra-sepakat-gugat-pergub-apba-dan-pergubcambuk

https://anzdoc.com/bab-ii-landasanteori7a2ecde0d71d8d383bb316db3b62c23e19397.html

https://www.academia.edu/5708875/TEORI_KEWENANGAN?auto=download https://media.neliti.com/media/publications/37009-ID-pembagian-kewenanganpemerintah-pusat-pemerintah-daerah-dalam-otonomi-seluas-lua.pdf

https://media.neliti.com/media/publications/220458-konsep-rechtsstaat-dalam-negarahukum-in.pdf

https://www.scribd.com/document/326281733/Pengaruh-Teori-Piramida-Hukum-HansKelsen-Dalam-Pembentukan-Undang-undang-Di-Indonesia https://kbbi.web.id/tempat 